\title{
RANCANG BANGUN SISTEM INFORMASI PENDAFTARAN MURID BARU SECARA ONLINE PADA PURWACARAKA PADANG
}

\author{
Larissa Navia Rani ${ }^{1}$, Desva Willton ${ }^{2}$ \\ Universitas Putra Indonesia "YPTK" Padang \\ E-mail: larissa_navia_rani@upiyptk.ac.id, desva.willton8@live.com
}

\begin{abstract}
Abstrak
Semakin berkembang pesatnya teknologi informasi saat ini, memicu semua kegiatan disemua bidang menggunakan teknologi dalam melakukan kegiatan operasionalnya tanpa terkecuali Purwacaraka Padang dalam melakukan pendaftaran murid baru. Sistem informasi pendaftaran murid baru secara online ini digunakan untuk mempermudah para calon murid mendaftar tanpa harus datang langsung ke Purwacaraka Padang. Selain itu dengan adanya aplikasi ini kegiatan-kegiatan yang dilakukan dapat di tampilkan di dalam aplikasi ini serta memberikan informasi terbaru kepada calon murid dan masyarakat. Adapun perancangan sistem ini menggunakan model UML (Unified Model Language) yang dapat memberikan gambaran bagaimana program berjalan serta interaksi antara aktor dengan sistem. Selain itu penggunaan bahasa pemrograman PHP yang didukung oleh database MySQL juga menjadikan sistem ini menjadi sebuah sistem informasi online yang bermanfaat.
\end{abstract}

Kata kunci: Pendaftaran, PHP, MySQL, Sistem Informasi, UML.

The rapid development of information technology today, triggering all activities in all fields of using technology in carrying out its operational activities without exception Purwacaraka Padang in registering new students. This new online student registration information system is used to make it easier for prospective students to register without having to come directly to Purwacaraka Padang. In addition, with this application the activities carried out can be displayed in this application and provide the latest information to prospective students and the community. The design of this system uses the UML model (Unified Model Language) which can provide an overview of how the program runs and the interaction between actors and systems. In addition, the use of the PHP programming language that is supported by MySQL databases also makes this system an useful online information system.

Keywords: Registration, PHP, MySQL, Information Systems, UML.

\section{Pendahuluan}

\section{Latar Belakang}

Perkembangan sistem informasi mengalami kemajuan yang sangat pesat, hal ini diakibatkan karena banyaknya dan beranekaragamnya data yang harus diolah dan disajikan dalam bentuk informasi. Sehingga penanganan sistem yang handal sangat dibutuhkan untuk menyelesaikan masalah tersebut. Tidak mudah untuk membuat sebuah laporan dengan menggunakan sistem manual maka mau tidak mau hampir semua aspek pekerjaan sudah beralih ke dalam pengolahan data secara komputerisasi karena cara ini dianggap lebih efektif.

Dengan melihat keluasan dan kedalaman peran sistem informasi di dalam sebuah organisasi, maka perlu dilakukan pengembangan sistem informasi. Mnurut Avison, et.al, 2006 [1] pengembangan sistem informasi sendiri didefinisikan sebagai proses penggalian gagasan, analisa, perancangan, dan penerapan suatu sistem informasi. Dan menurut Hoffer, et.al, 2011 [1] 
pengembangan sistem informasi berbasis komputer merupakan kegiatan yang kompleks, memakan biaya dan sumber daya relatif besar, dan merupakan kegiatan esensial dalam setiap organisasi.

Setiap organisasi pasti memiliki sistem informasi. Baik sistem informasi formal maupun sistem informasi nonformal. Sistem informasi informal terdiri atas gosip, isu, dan lainnya. Begitupun dengan organisasi yang ada di Purwacaraka Padang yang memiliki sistem informasi formal. Purwacaraka sendiri adalah sekolah musik nonformal yang sedang berkembang dan selalu ingin mengikuti perkembangan teknologi informasi saat ini. Bidang administrasi yang selama ini masih sulit untuk dikerjakan karena masih menggunakan format manual. Hal ini dapat menyebabkan penggunaannya menjadi kurang efisien. Salah satunya adalah permasalahan yang sering muncul dalam hal pelayanan administrasi pendaftaran murid baru. Pencatatan yang masih manual masih mengharuskan murid atau orang tua untuk datang langsung ke sekolah musik tersebut. Salah satu upaya untuk mengatasi masalah tersebut adalah dengan menciptakan suatu sistem yang terkomputerisasi. Hal ini penting dilakukan guna meningkatkan efisiensi dan efektifitas kerja.

Untuk memenuhi kebutuhan sistem, digunakanlah bahasa pemrograman PHP (Personal Home Page) yang mana bahasa pemograman ini bersifat server-side. Server-side yang dimaksud di sini adalah PHP hanya akan berjalan pada aplikasi berbasis server, baik itu server yang berjalan di komputer lokal (localhost) maupun server yang berjalan secara online [2].

PHP (Hypertext Preprocessor), merupakan bahasa pemrograman pada sisi server yang memperbolehkan programmer menyisipkan perintah-perintah perangkat lunak web server (Apache, IIS, atau apapun) akan dieksekusi sebelum perintah itu dikirim oleh halaman ke browser yang memintanya, contohnya adalah bagaimana memungkinkannya memasukkan tanggal sekarang pada sebuah halaman web setiap kali tampilan tanggal dibutuhkan. Sesuai dengan fungsinya yang berjalan di sisi server maka PHP adalah bahasa pemrograman yang digunakan untuk membangun teknologi web application [3].

Keuntungan menggunakan bahasa pemrograman PHP adalah bisa digunakan secara gratis (free) dan bersifat open source. Mampu terkoneksi dengan banyak pilihan database, dalam sisi pemahaman lebih mudah karena memiliki referensi yang banyak dan didukung oleh berbagai macam web server dengan konfigurasi yang relatif mudah.

\section{Perumusan Masalah}

Untuk mendapatkan pelayanan pendaftaran yang baik dan terkomputerisasi, maka terdapat beberapa masalah:

1. Apakah pendaftaran secara online ini dapat mempermudah orang tua atau murid untuk mendaftar?

2. Bagaimana sistem yang dirancang bisa membantu Purwacaraka Padang dalam mengolah data murid baru?

3. Apakah dengan dirancangnya sistem informasi pendaftaran ini dapat mempermudah Purwacaraka Padang dalam menyampaikan informasi?

\section{Tujuan Penelitian}

Adapun tujuan dari penelitian ini, adalah sebagai berikut:

1. Mempermudah calon murid baru atau orang tua dari murid untuk mendaftar di Purwacaraka Padang.

2. Mempermudah para staff dari Purwacaraka mengelola data calon murid yang mendaftar.

3. Mempermudah Purwacaraka Padang dalam menyampaikan informasi .

\section{Manfaat Penelitian}

Adapun manfaat dari penelitian ini adalah sebagai berikut:

1. Beberapa manfaat bagi peneliti adalah: 
a. Menambah pengalaman serta pengetahuan dalam pembuatan sistem pendaftaran murid baru secara online.

b. Terciptanya hubungan yang baik antara penulis dengan pihak Purwacaraka.

2. Beberapa manfaat bagi masyarakat adalah:

a. Mempermudah Purwacaraka dalam pengolahan data siswa baru.

b. Mempermudah pendaftar dalam mencari informasi.

3. Manfaat bagi universitas adalah:

a. Menghasilkan lulusan yang mampu terjun ke lapangan kerja.

b. Membantu para mahasiswa untuk mendapatkan referensi dari penelitian ini.

\section{Tinjauan Literatur}

\section{Sistem}

Sistem adalah kumpulan atau himpunan dari unsur atau variabel-variabel yang saling terkait, saling berinteraksi, dan saling tergantung satu sama lain untuk mencapai tujuan [4].

\section{Informasi}

Informasi adalah hasil pemprosesan data yang diperoleh dari setiap elemen sistem tersebut menjadi bentuk yang mudah dipahami dan merupakan pengetahuan yang relevan yang dibutuhkan oleh orang untuk menambah pemahamannya terhadap fakta yang ada [5].

\section{Sistem Informasi}

Sistem informasi adalah kumpulan elemen yang saling berhubungan satu sama lain yang membentuk satu kesatuan untuk mengintegrasikan data, memproses dan menyimpan serta mendistribusikan informasi [6].

\section{UML}

UML adalah bahasa pemodelan untuk sistem atau perangkat lunak yang berparadigma (berorientasi objek) [7].

\section{Database}

Basis data terdiri atas dua kata, yaitu basis dan data. Basis kurang lebih dapat diartikan sebagai markas atau gudang, tempat bersarang atau berkumpul. Sedangkan data adalah representasi fakta dunia nyata yang mewakili suatu objek seperti manusia (pegawai, siswa, pembeli, pelanggan), barang, hewan, angka, huruf, simbol, teks, gambar, bunyi, atau kombinasinya [8].

\section{Pengertian PHP}

PHP adalah bahasa server-side scripting yang menyatu dengan HTML untuk membuat halaman web yang dinamis. Maksud dari server-side scripting adalah sintaks dan perintahperintah yang diberikan akan sepenuhnya akan dijalankan di server tetapi disertakan pada dokumen HTML. Pembuatan web ini merupakan kombinasi antara PHP sendiri sebagai bahasa pemrograman dan HTML sebagai penbangun halaman web [9].

\section{Internet}

Internet adalah singkatan dari Interconnected Network. Internet merupakan sebuah sistem komunikasi yang mampu menghubungkan jaringan-jaringan komputer diseluruh dunia [9].

\section{Pendaftaran}

Pengertian pendaftaran di sini pada dasarnya hanya untuk memperlancar dan mempermudah dalam proses pendaftaran siswa siswi baru, pendataan dan pembagian kelas 
seorang siswa siswi. Sehingga dapat terorganisir, teratur dengan cepat dan tepat dengan beberapa persyaratan yang telah ditentukan oleh sekolah ataupun suatu lembaga pendidikan [10].

\section{Analisa dan Hasil}

\section{Analisa Sistem yang Sedang Berjalan}

Analisa sistem yang sedang berjalan di Purwacaraka Padang saat ini adalah untuk pengisian formulir dan pencatatan data murid baru masih menggunakan format manual yang membuat para orang tua harus mendatangi tempat sekolah musik tersebut. Terlebih para orang tua atau murid memiliki kesibukan-kesibukan tertentu sehingga membuat orang tua atau murid telat untuk mendaftar dikarenakan harus memiliki jadwal yang kosong untuk bisa pergi ke Purwacaraka hanya untuk mendaftar saja dan itupun harus memakan waktu yang relatif lama. Serta para staff dari Purwacaraka sering mengalami kesulitan dan kehilangan data terkait pengisian data yang masih dilakukan secara manual.

\section{Analisa Bentuk Sistem Baru}

Maka untuk mendukung dari alternatif pemecahan masalah diatas dibentuklah sebuah sistem atau aplikasi baru, dimana aplikasi tersebut dapat membantu murid atau orang tua untuk mendaftar di sekolah musik Purwacaraka. Metode yang digunakan cukup sederhana, murid atau orang tua cukup mengakses domain yang telah ditentukan dan mengisi formulir pendaftaran yang tertera di halaman pendaftaran.

\section{Uses Case Diagram}

Use Case menggambarkan bagaimana seseorang akan menggunakan atau memanfaatkan sistem, sedangkan aktor adalah seseorang atau sesuatu yang berinteraksi dengan sistem. Use Case diagram menggambarkan bagaimana proses-proses yang dilakukan oleh aktor terhadap sebuah sistem.

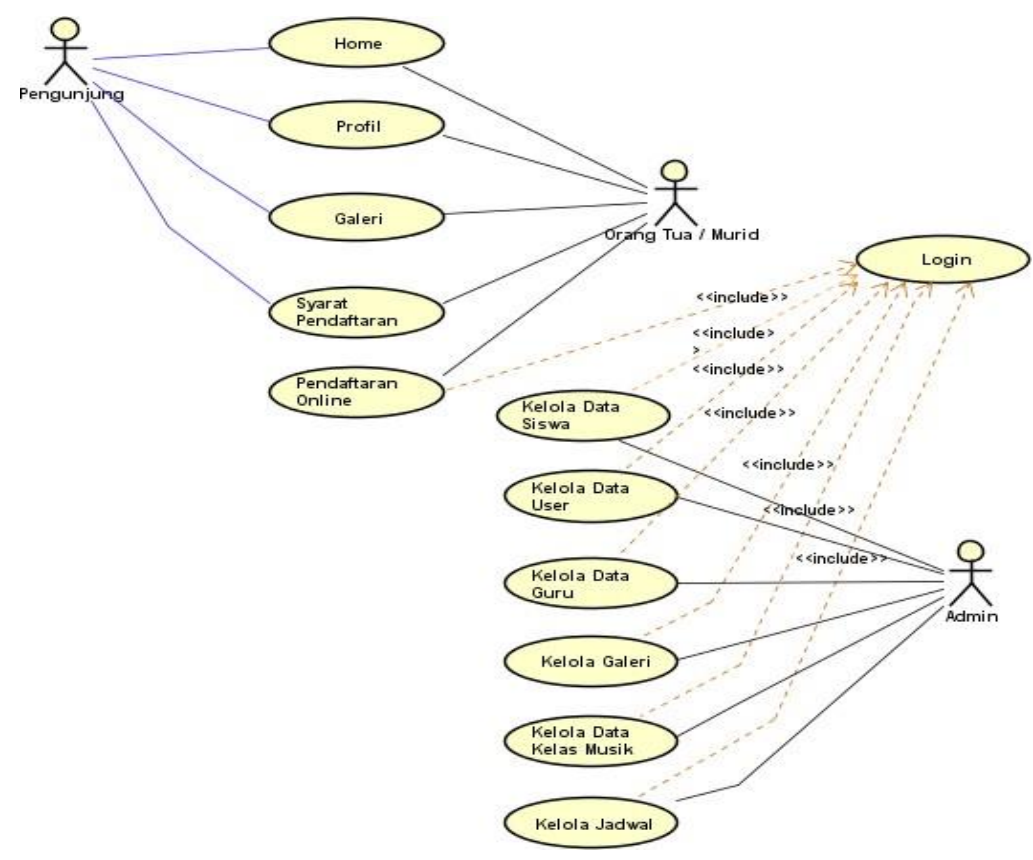

Gambar 1 : Use Case Diagram 
Pada bagian ini akan dijabarkan aktor yang terlibat dalam sistem pendaftaran murid baru secara online di Purwacaraka Padang. Untuk mengetahui definisi aktor yang ada pada use case diagram dapat dilihat pada Tabel 1 berikut :

Table 1: Definisi Aktor

\begin{tabular}{|c|l|l|}
\hline No & \multicolumn{1}{|c|}{ Aktor } & \multicolumn{1}{c|}{ Peran } \\
\hline 1 & Pengunjung & $\begin{array}{l}\text { Sebagai pengunjng website tidak bisa melakukan login dan } \\
\text { pengisian formulir pendaftaran }\end{array}$ \\
\hline 2 & User & $\begin{array}{l}\text { Sebagai pengguna bisa melakukan login dan mengisi } \\
\text { formulir pendaftaran }\end{array}$ \\
\hline 3 & Admin & Sebagai administrator yang memanajemen sistem \\
\hline
\end{tabular}

\section{Class Diagram}

Class diagram memberikan gambaran hubungan antara tabel-tabel yang ada dalam database. Masing-masing class memiliki attribute dan metoda atau fungsi sesuai dengan proses yang terjadi.

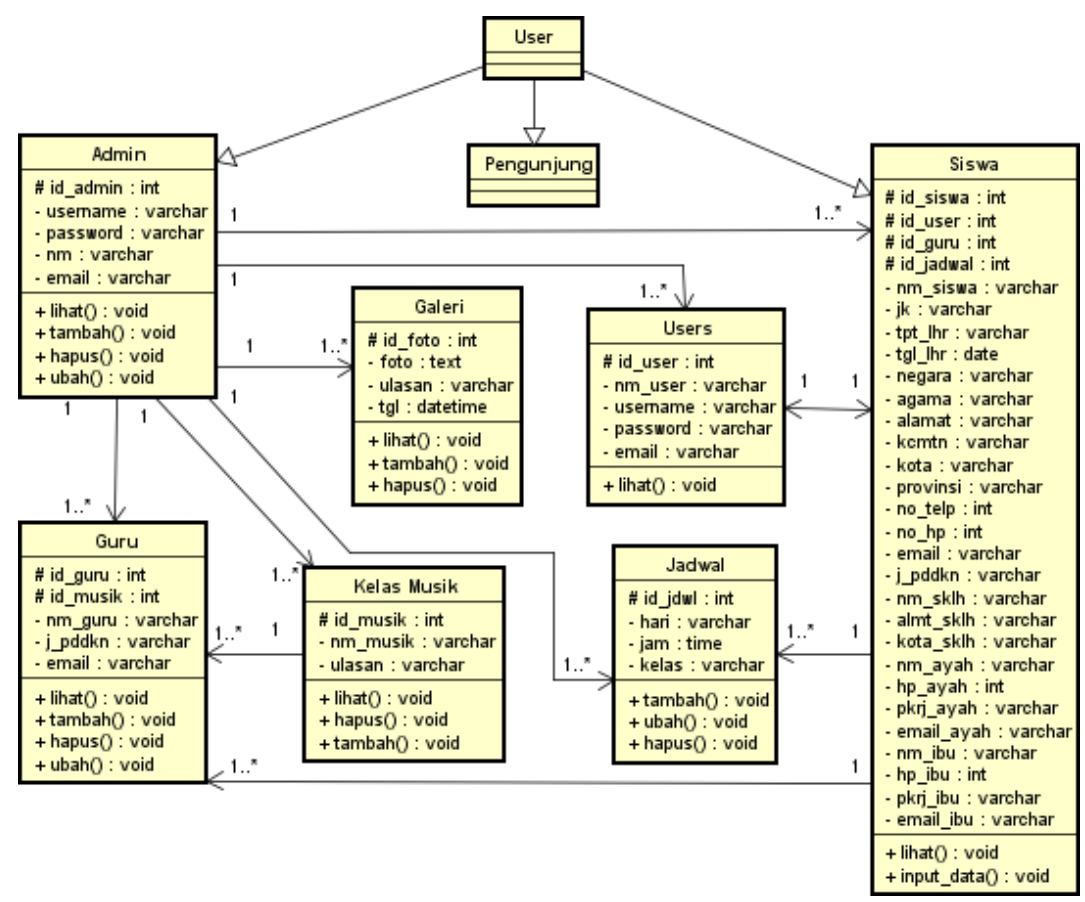

Gambar 2 : Class Diagram

\section{Activity Diagram}

Activity Diagram menggambarkan bagaimana aktivitas yang terjadi dalam sistem yang akan dirancang. Activity diagram sama seperti halnya flowchart yang menggambarkan proses yang terjadi antara aktor dan sistem.

Activity diagram pengunjung menggambarkan bagaimana aktivitas yang terjadi pada pengunjung dan sistem. Pengunjung mengakses sistem informasi yang akan diarahkan oleh sistem ke menu utama sistem informasi. Setelah itu pengunjung memilih aktifitas apa yang akan dilakukan, yang dapat dilihat pada gambar 3 berikut ini: 


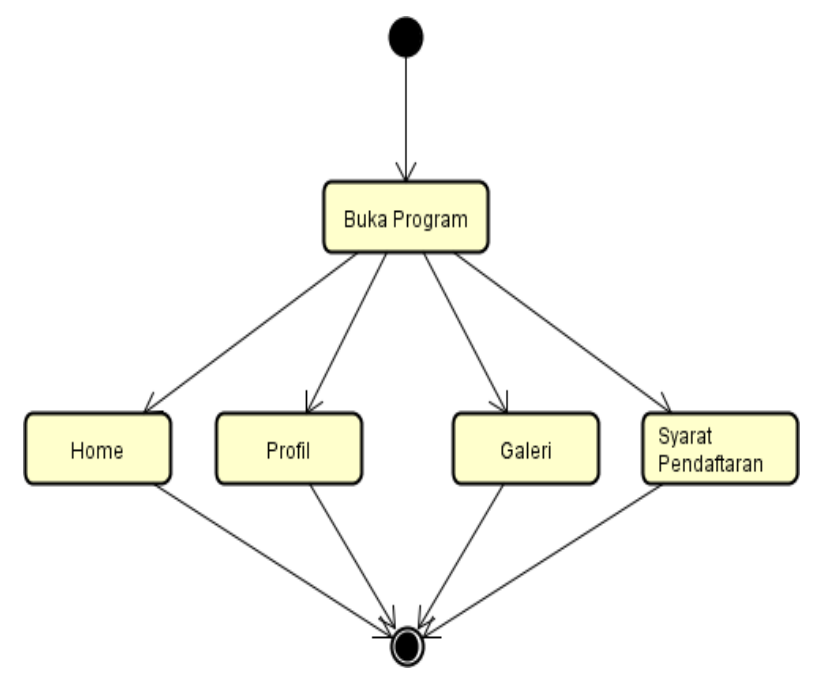

Gambar 3: Activity Diagram Pengunjung

Activity diagram siswa menggambarkan bagaimana aktifitas yang terjadi pada siswa dan sistem. Siswa mengakses sistem informasi dan melakukan login, apabila siswa belum memiliki akun untuk melakukan pendaftaran online siswa tersebut harus melakukan register yang bertujuan untuk mendapatkan username dan password. Kemudian setelah berhasil login, siswa akan diarahkan oleh sistem ke form formulir pendaftaran online. Yang dapat dilihat pada gambar 4 berikut ini:

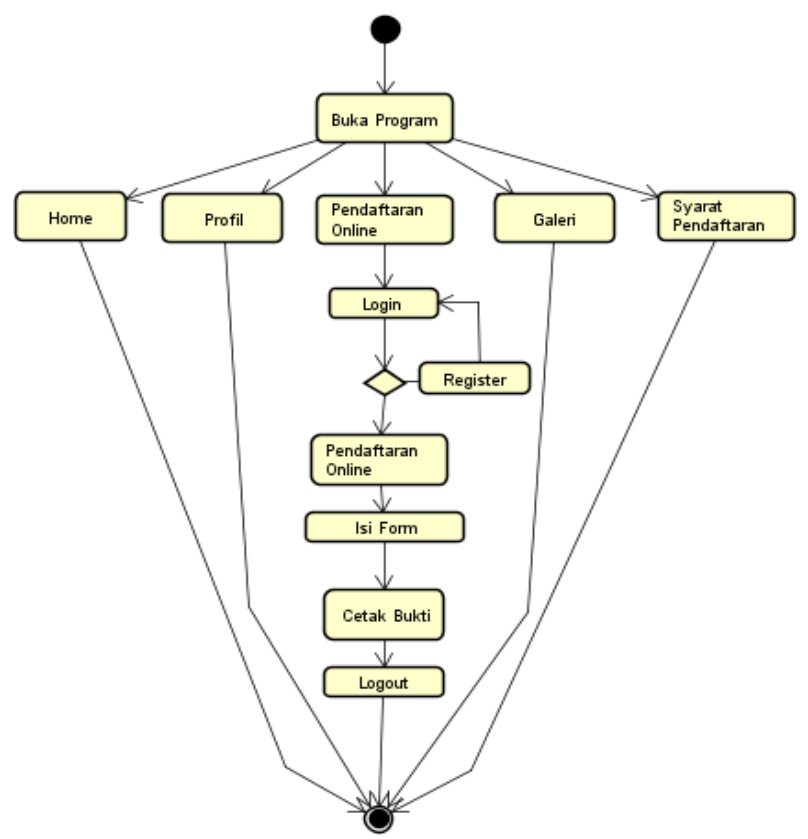

Gambar 4: Activity Diagram Siswa

Activity diagram admin menggambarkan bagaimana aktivitas yang terjadi pada admin dan sistem. Admin mengakses sistem informasi dan melakukan login, kemudian admin akan diarahkan oleh sistem ke menu utama sistem informasi. Setelah itu admin memilih aktifitas apa yang akan dilakukan, yang dapat dilihat pada gambar 5 berikut ini: 


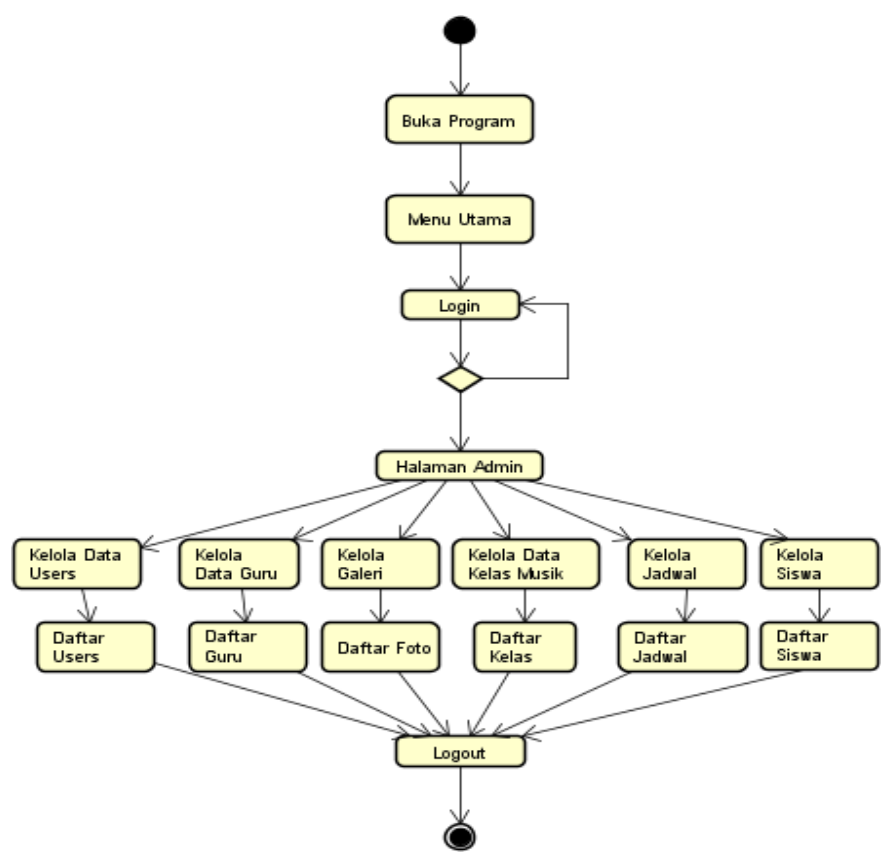

Gambar 5: Activity Diagram Admin

\section{Tampilan home}

Merupakan halaman utama pada sistem Purwacaraka Padang yang otomatis diakses oleh sistem saat pertama kali mengunjungi website seperti pada gambar 6 berikut :
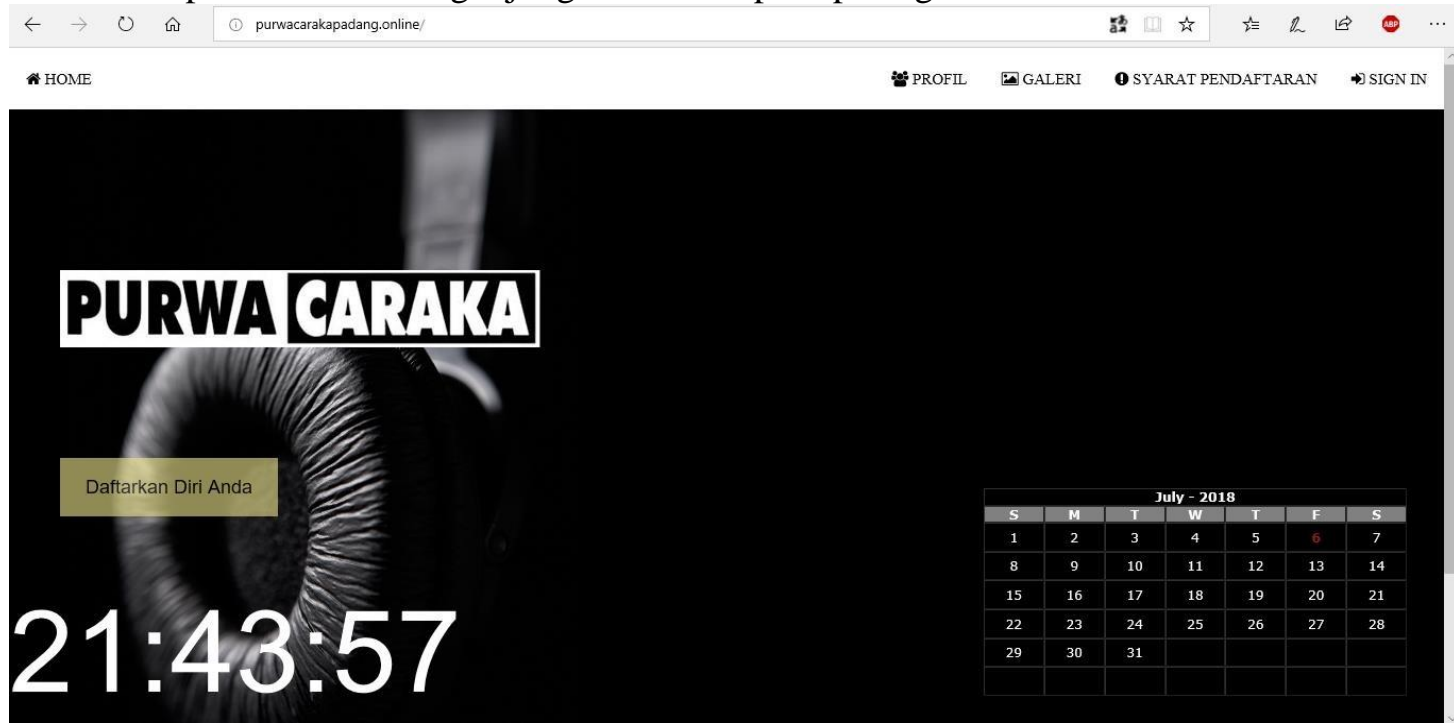

Gambar 6: Halaman Utama

\section{Halaman Login User}

Merupakan halaman masuk untuk bisa mengakses hak-hak yang dimiliki oleh user untuk mengisi formulir pendaftaran seperti pada gambar 7 berikut : 


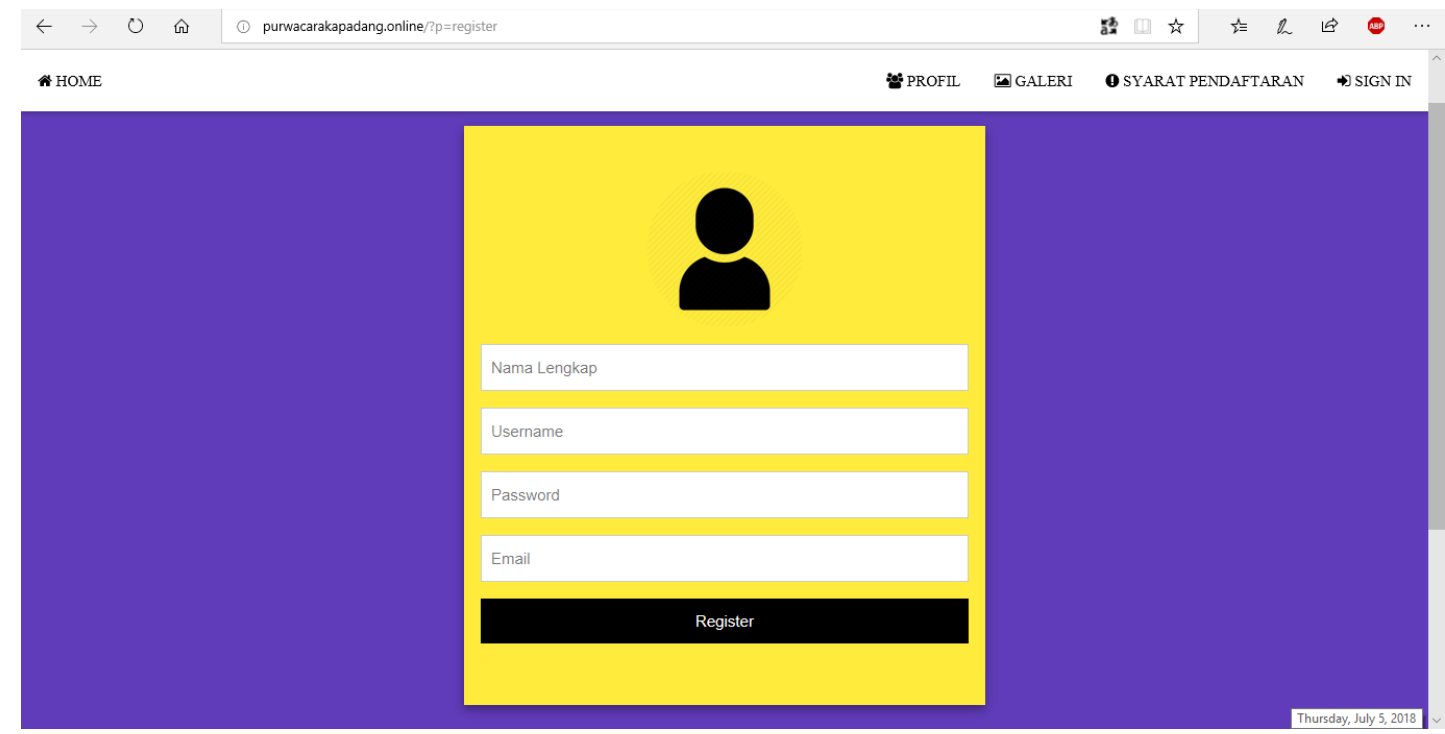

Gambar 7: Halaman Login User

\section{Halaman Formulir Pendaftaran}

Halaman yang berisikan form untuk menginputkan data calon siswa yang ingin mendaftar di Purwacaraka Padang seperti gambar 8 berikut:

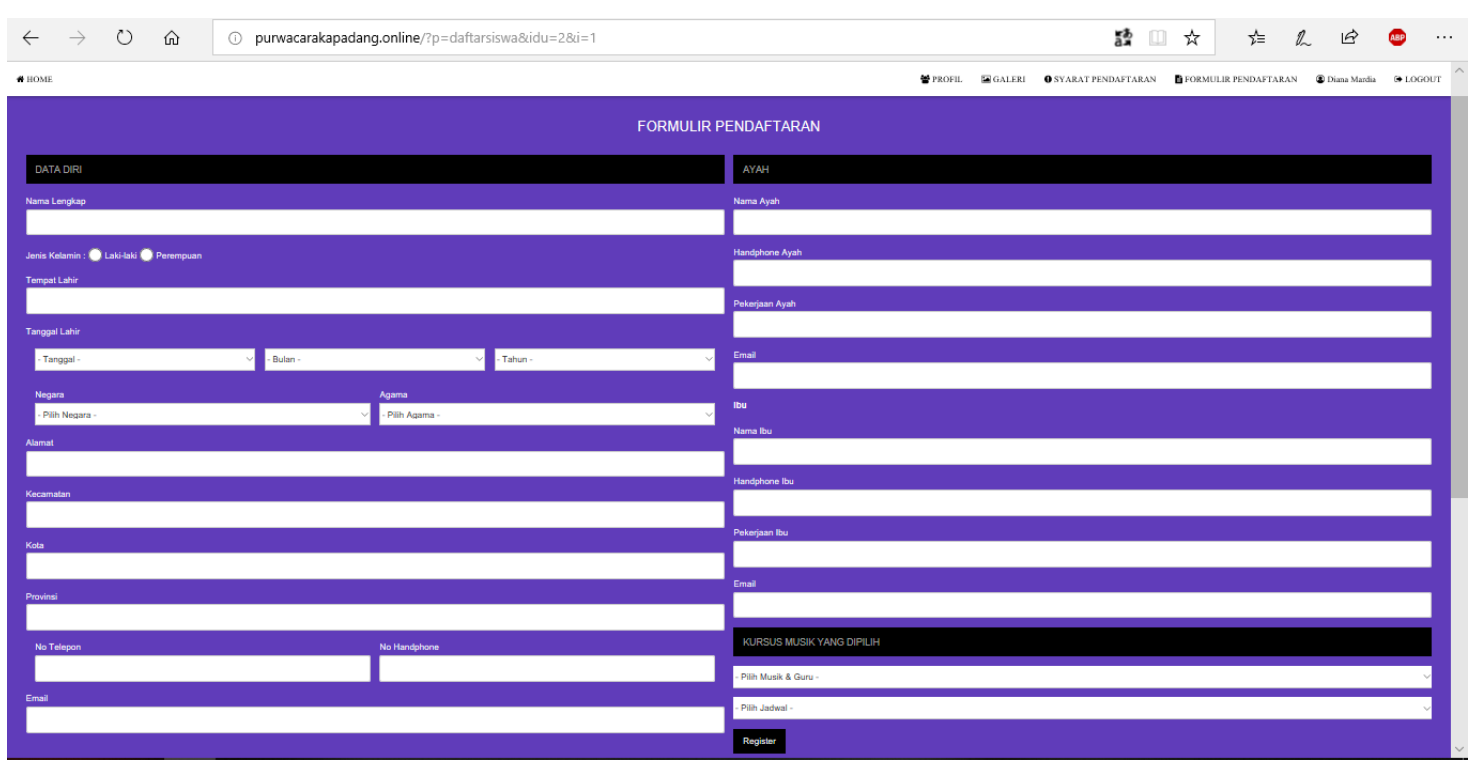

Gambar 8: Halaman Formulir Pendaftaran

\section{Laporan Data Siswa}

Laporan semua data siswa pada Purwacaraka Padang seperti pada gambar 9 berikut : 


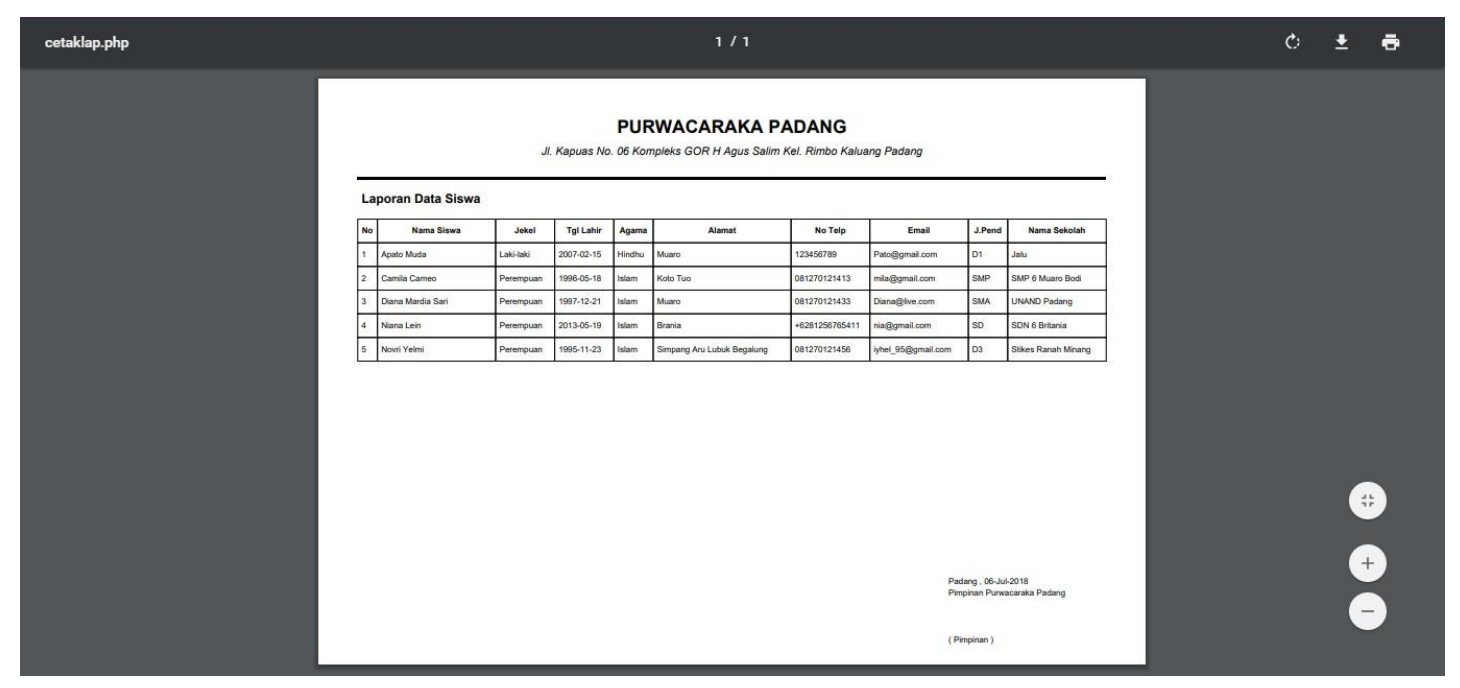

Gambar 9: Laporan Data Siswa

\section{Laporan Bukti Pendaftaran Siswa Baru}

Laporan bukti pendaftaran siswa pada Purwacaraka Padang dapat dilihat seperti gambar 10 berikut :

\begin{tabular}{|c|c|c|}
\hline \multicolumn{3}{|c|}{$\begin{array}{l}\text { PURWACARAKA PADANG } \\
\text { No. Os Kampleks } G O R \mathrm{H} \text { Aqus Salim Kel. Rimbo Kaluang Padang }\end{array}$} \\
\hline \multicolumn{3}{|l|}{ Tanda Bukti Pendaftaran Online } \\
\hline Nama Lengkap & Diana Mardia Sari & \\
\hline \begin{tabular}{|l|} 
Jenis Kelamin \\
\end{tabular} & Perempuan & \\
\hline Tempat / Tanggal Lahir & Koto Tuo & \\
\hline Negara & Indonesia & \\
\hline Agama & Islam & \\
\hline Alamat & Muaro & \\
\hline Kecamatan & Koto VII & \\
\hline Kota & Solok & \\
\hline Provinsi & Sumatera Utara & \\
\hline Phone 1 & 081256039231 & \\
\hline Phone 2 & 081270121433 & \\
\hline Email & Diana@live.com & \\
\hline \begin{tabular}{|l} 
Jenjang Pendidikan \\
\end{tabular} & SMA & \\
\hline Nama Sekolah & UNAND Padang & \\
\hline Alamat Sekolah & Alai & \\
\hline Kota Sekolah & Solok & \\
\hline Nama Ayah & John & \\
\hline Phone Ayah & 081270121434 & \\
\hline Pekerjaan Ayah & Tani & \\
\hline Email Ayah & John@gmail.com & \\
\hline Nama tbu & Siti & \\
\hline Phone lbu & 081270121435 & \\
\hline Pekerjaan ibu & Ibu Rumah Tangga & \\
\hline Email Ibu & Siti@gmail.com & \\
\hline \multicolumn{3}{|c|}{ Catatan : - Wajpb bawa bukti pembayaran ketika menyerahkan ini. } \\
\hline - Anda memīh kursus : & Vocal dan pengajar : Kurniawan Fernando & hari : Jumat jam : 14:00:00 \\
\hline & & Foto \\
\hline
\end{tabular}

Gambar 10: Laporan Bukti Pendaftaran Siswa Baru 


\section{Kesimpulan dan Saran}

\section{Kesimpulan}

Berdasarkan analisa penelitian yang dilakukan maka penulis dapat mengambil kesimpulan sebagai berikut :

1. Sistem yang dihasilkan dapat memudahkan calon siswa atau orang tua untuk mendaftar di Purwacaraka Padang tanpa perlu datang langsung ke tempat.

2. Analisa dan perancangan sistem ini dapat digunakan sebagai acuan dalam pembuatan sistem pada tahap selanjutnya.

\section{Saran}

Setelah beberapa kesimpulan yang dikemukakan oleh penulis terhadap sistem informasi pendaftaran online pada Purwacaraka Padang, ada beberapa saran yang sebaiknya dilakukan pemakai sistem.

1. Dalam penerapan sistem ini sebaiknya didukung oleh suberdaya yang cukup memadai seperti brainware (manusia) yang dapat di percaya dan bertanggung jawab dari segi perangkat keras (hardware) yang bagus sehingga dapat mengoperasikan sistem yang baru dengan baik dan benar.

2. Memberikan pengetahuan terhadap pemakai sistem dalam menggunakan sistem yang baru seperti bagian data agar nantinya tidak ada kekeliruan dalam penginputan datadata.

\section{Referensi}

[1] Sarosa, Samiaji.2017. "Metodologi Pengembangan Sistem Informasi”. Jakarta: Indeks Jakarta.

[2] Hariyanto, Agus.2017. "Membuat Aplikasi Computer Based Test dengan PHP MySQLi dan Bootstrap". Yogyakarta: Lokomedia.

[3] Zuliarso Eri dan Herny Februariyanti.2013. "Sistem Informasi Perpustakaan Elektronik Berbasis Web". ISSN(0854-9524), Volume.19, No.1.

[4] Tohari, Hamim.2014. "Analisa Serta Perancangan Sistem Informasi Melalui Pendekatan UML". Yogyakarta: Andi Offset.

[5] Putri, Lely Deviana.2014. "Perancangan Sistem Informasi Penerimaan Siswa Baru pada Sekolah Menengah Kejuruan Negeri 3 Pacitan”. ISSN(2302-5700), Volume.3, No.4.

[6] Rahmad, Mhd Bustanur dan Tedy Setyadi.2014. "Perancangan Sistem Informasi Inventory Spare Part Elektronik Berbasis Web PHP (Studi CV. Human Global Service Yogyakarta)". ISSN(2338-5197), Volume.2, No.2.

[7] Azwanti, Nurul.2017. "Sistem Informasi Penjualan Tas Berbasis Web Dengan Pemodelan UML”. ISSN(2406-7857), Volume.4, No.1.

[8] Fatansyah.2015. "Basis Data". Bandung: Informatika Bandung.

[9] Hendriyanto, Dani Eko.2014. "Pembuatan Sistem Informasi Perpustakaan Berbasis Website Pada Sekolah Menengah Pertama Negeri 1 Donorojo Kabupaten Pacitan”. ISSN(2302-5700), Volume.3, No.4.

[10] Poerwandono, Wienda Gatoet, Tjatursari Widiartin dan Noven Indra Prasetya.2017. "Sistem Pendaftaran Siswa Baru Untuk Mengklasifikasikan Kelas di MTS Darussalam Jombang”. pISSN(2442-3386), eISSN(2442-4293), Volume.3, No.1. 